\title{
OCCURRENCE AND DISTRIBUTION
}

\section{OF SPECIAL STATUS PLANT SPECIES}

ON THE NAVAL PETROLEUM

RESERVES IN CALIFORNIA

by

David C. Anderson, Brian L. Cypher, Gary L. Holmstead,

Kristie L. Hammer, and Nancy Frost

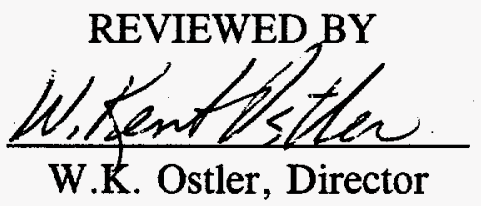

Environmental Sciences Division

This Document is UNCLASSIFIED

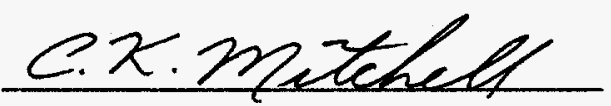

C.K. Mitchell

Classification Officer

OCTOBER 1994

Work was performed by EG\&G/EM, Environmental Sciences Division for the U. S. Department of Energy, Naval Petroleum Reserves in California, and Chevron U.S.A. Production Company under DOE Contract No. DE-AC08-93NV11265 


\section{DISCLAIMER}

This report was prepared as an account of work sponsored by an agency of the United States Government. Neither the United States Government nor any agency thereof, nor any of their employees, make any warranty, express or implied, or assumes any legal liability or responsibility for the accuracy,. completeness, or usefulness of any information, apparatus, product, or process disclosed, or represents that its use would not infringe privately owned rights. Reference herein to any specific commercial product, process, or service by trade name, trademark, manufacturer, or otherwise does not necessarily constitute or imply its endorsement, recommendation, or favoring by the United States Government or any agency thereof. The views and opinions of authors expressed herein do not necessarily state or reflect those of the United States Government or any agency thereof. 


\section{DISCLAIMER}

Portions of this document may be illegible in electronic image products. Images are produced from the best available original document. 


\section{ACKNOWLEDGEMENTS}

Dr. Ellen Cypher of the San Joaquin Valley Endangered Species Recovery Team contributed her time and knowledge of the distribution of many species and frequently provided taxonomic expertise. Her assistance is appreciated. We recognize the efforts of Dr. Cypher, Randi McCormick and Wendy Stevens of the local chapter of the California Native Plant Society for time spent surveying portions of the Naval Petroleum Reserves in California. Susan Carter and Russ Lewis, from the Bureau of Land Management Caliente Resource Area, provided information on the local distribution of several of the special status plant species for which we express our appreciation. 


\section{CONTENTS}

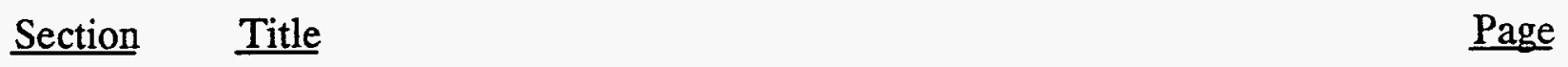

ACKNOWLEDGEMENTS $\ldots \ldots \ldots \ldots \ldots \ldots \ldots \ldots \ldots$ ii

1. INTRODUCTION $\ldots \ldots \ldots \ldots \ldots \ldots \ldots \ldots \ldots \ldots \ldots \ldots \ldots \ldots$

2. OBJECTIVES $\ldots \ldots \ldots \ldots \ldots \ldots \ldots \ldots \ldots \ldots \ldots \ldots \ldots \ldots \ldots \ldots \ldots \ldots \ldots$

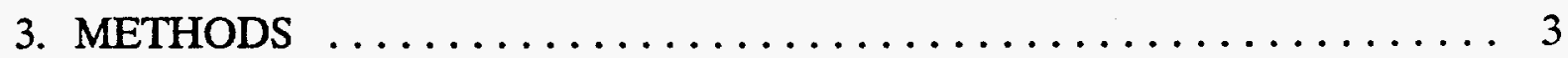

3.1 INFORMATION SEARCH $\ldots \ldots \ldots \ldots \ldots \ldots \ldots \ldots \ldots \ldots \ldots$

3.2 SELECTION OF SURVEY AREAS $\ldots \ldots \ldots \ldots \ldots \ldots \ldots, 3$

3.3 FIELD SURVEYS $\ldots \ldots \ldots \ldots \ldots \ldots \ldots \ldots \ldots \ldots$

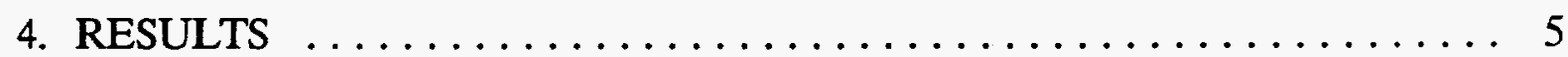

4.1 INFORMATION SEARCH $\ldots \ldots \ldots \ldots \ldots \ldots \ldots \ldots \ldots$

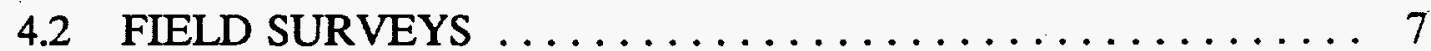

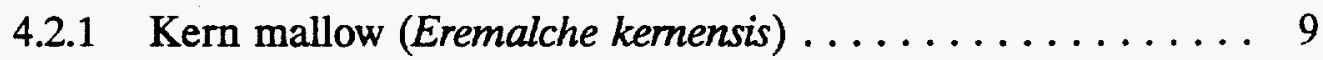

4.2.2 San Joaquin wooly-threads (Lembertia congdonii) . . . . . 10

4.2.3 California jewelflower (Caulanthus californica) $\ldots \ldots \ldots 10$

4.2.4 Hoover's wooly-star (Eriastrum hooveri) . . . . . . . . 11

4.2.5 Lost Hills saltbush (Atriplex vallicola) . . . . . . . . 11

4.2.6 Hollisteria (Hollisteria lanata) $\ldots \ldots \ldots \ldots \ldots \ldots \ldots . \ldots \ldots \ldots$

4.2.7 Heartscale (Atriplex cordulata) . . . . . . . . . . 12

4.2.8 Recurved larkspur (Delphinium recurvatum) . . . . . . 13

4.2.9 Bakersfield saltbush (Atriplex tularensis) . . . . . . . . 13

4.2.10 Forked fiddleneck (Amsinckia vernicosa var. furcata) . . . . 14

4.2.11 Comanche Point layia (Layia leucopappa) . .......... 14

4.2.12 Alkali Mariposa lily (Calochortus striatus) .......... 15

4.2.13 Hispid bird's-beak (Cordylanthus mollis hispidus) . . . . . . 15

4.2.14 Slough thistle (Cirsium crassicaule) ............. 16

5. DISCUSSION AND RECOMMENDATIONS $\ldots \ldots \ldots \ldots \ldots \ldots \ldots$

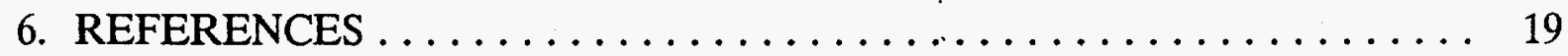

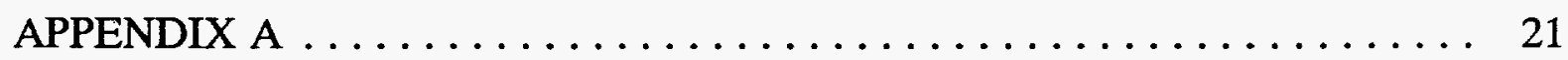

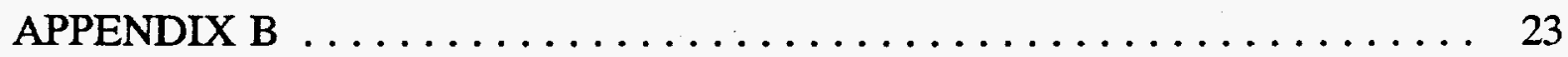

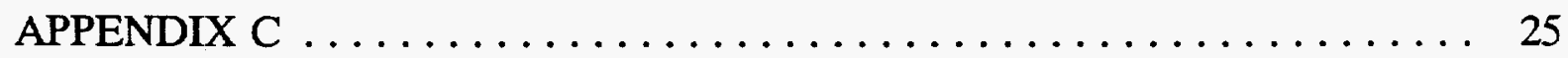




\section{INTRODUCTION}

Several special status plant species occur or potentially occur at the Naval Petroleum Reserves in California (NPRC). Special status species are defined as those species that are either federally listed as endangered or threatened, or candidate taxa. Candidate species are classified as Category 1 or Category 2. Category 1 taxa are those species for which there is sufficient evidence to support listing, while Category 2 taxa are those species for which listing may possibly be appropriate, but for which sufficient data are lacking to warrant immediate listing. Determining the presence and distribution of these species on NPRC is necessary so that appropriate conservation or protection measures can be implemented.

In the spring of 1988, a survey of Naval Petroleum Reserve No. 1 (NPR-1) was conducted to determine the occurrence of Hoover's wooly-star (Eriastrum hooveri), Kern Mallow (Eremalche kernensis), San Joaquin wooly-threads (Lembertia congdonii), and California jewelflower (Caulanthus californicus), all listed by the U.S. Fish and Wildlife Service (FWS) as Category 2 species at that time. Of the four species, only Hoover's wooly-star was found (EG\&G Energy Measurements, Inc., 1988). It was concluded that Kern mallow and San Joaquin wooly-threads could potentially be found on NPR-1, but habitat for California jewelflower did not occur on NPR-1 and its occurrence was unlikely.

Annual plant production was low in 1988 and botanists conducting the surveys recommended that additional surveys be conducted for Kern mallow and San Joaquin wooly-threads when growing conditions were more favorable (EG\&G Energy Measurements, Inc., 1992a). A second survey was conducted in the spring of 1991, following above or near average spring precipitation which created favorable growing conditions for annual plants. The primary objective of the survey was to document the distribution of Hoover's wooly-star. Habitat for San Joaquin wooly-threads and Kern mallow is somewhat similar to that of Hoover's wooly-star so during the course of the survey potential habitat for those two species was also surveyed. Numerous populations of Hoover's wooly-star were located during the 1991 survey. However, as in 1988, neither San Joaquin wooly-threads nor Kern mallow were found (EG\&G Energy Measurements, Inc., 1992b).

As part of an ongoing effort to document the presence or absence of sensitive plant species on NPRC, surveys for species other than Hoover's wooly-star were conducted in the spring of 1993. Abundant spring rains in 1993 created favorable growing conditions for annual forbs. Surveys in 1993 focused on potential habitat of several endangered and candidate species. The results of those surveys are presented in this report. 


\section{OBJECTIVES}

The goal of this report is to assess the status of listed and candidate plant species on NPRC. The three principal objectives of this survey were to:

- Review existing literature and determine which candidate plant species are most likely to occur on NPRC.

* Conduct a floristic survey for those federally listed or candidate plant species potentially occurring on NPRC.

* Identify future survey, monitoring, management, and/or study needs to assess the status of sensitive status plant species on NPRC and ensure their conservation. 


\section{METHODS}

\subsection{INFORMATION SEARCH}

Literature sources were reviewed to identify and categorize special status plant species according to their potential for occurring on NPRC. The main sources of information used to identify special status plant species which may occur on NPRC were U.S. Fish and Wildlife Service's (FWS) list of species in the Federal Register (1990). The Federal Register information included a review of the plant taxa proposed for listing as endangered or threatened species. This list was used to determine which species occur in California and, where possible, to determine which were likely to occur in Kern County. Occurrence in Kern County was further validated by reviewing the California Native Plant Society's (1988) Inventory of Rare and Endangered Vascular Plants of California, and California Department of Fish and Game's (CDFG) (1992a) list of designated endangered, threatened, or rare plants and candidates.

The resulting list of plants was further scrutinized to determine which species were most likely to be found on NPRC. Potential occurrence of species on NPRC was based on historical and current distributions of species and species' habitat requirements (i.e., topography, elevation, soil types, associated species) relative to habitat conditions on NPRC. Previous survey reports and baseline information on threatened or endangered plants were reviewed (e.g., Taylor and Davilla, 1986; EG\&G Energy Measurements, Inc., 1988; U.S. Fish and Wildlife Service, 1989; EG\&G Energy Measurements, Inc., 1992a; 1992b) to determine habitat preferences and known distributions of the species. The Natural Diversity Database (NDDB) (California Department of Fish and Game, 1992b) was also accessed to identify collections or occurrences of the special status plant species on or in the vicinity of NPRC.

Additional information was obtained from other researchers working on special status plant species in the San Joaquin Valley. This effort was facilitated by an interagency plant research coordination meeting in February, 1993, in which the San Joaquin Valley Endangered Species Recovery Planning Program (SJVESRPP), U.S. Bureau of Land Management (BLM), FWS, The Nature Conservancy, and CDFG were represented. Also, EG\&G Energy Measurements, Inc. (EG\&G/EM) staff visited SJVESRPP, BLM, and CDFG research plots on the nearby Carrizo Plain to become familiar with habitat preferences of several special status plant species.

\subsection{SELECTION OF SURVEY AREAS}

The potential occurrence of each of the special status plant species on NPRC was categorized as high, moderate or low. The categorization was based on the amount of potential habitat found on NPRC, and the proximity of known locations of the species to NPRC. Proximity of known location to NPRC usually was the more important criteria. 
Once a list of special status plant species was identified the habitat for each species was plotted on 7.5-minute topographic maps. Surveys focused on habitat of those species with high or moderate probability for occurrence on NPRC. Due to the limited amount of time and staff, it was not possible to survey all areas in their entirety.

\subsection{FIELD SURVEYS}

Field surveys were conducted at the time of peak production for each plant species, as determined by staff experience and literature on individual species (Munz and Keck, 1959; Taylor and Davilla, 1998; Hlickman, 1993). Surveys began in early April and were completed in mid-June. A meander survey method (Nelson, 1987) was used to search for the species. When a special status plant species was encountered, its location was plotted as accurately as possible on field maps. Site information was recorded on a NDDB form (Appendix A) and on a NPRC Plant Population Site Characterization form (Appendix B). A photograph was taken, and if the species was not currently listed as endangered or threatened, a voucher specimen was collected, pressed, mounted, and filed in the DOE/NPRC herbarium. 


\section{RESULTS}

\subsection{INFORMATION SEARCH}

Fourteen special status plant species were identified as potentially occurring on NPRC (Table 1). These species include four federally listed threatened or endangered species and ten federal Category 2 species. No Category 1 species were identified. Three of the 14 species have been located on NPRC or have been reported to occur on NPRC and were consequently categorized as having a 'high' potential for occurrence on NPRC. Four other species are known to occur in the vicinity of NPRC and were categorized as moderate potential for occurrence. None of the remaining seven species are known to occur on NPRC and their preferred habitat is rare on NPRC. None of these species are likely to occur on NPRC and were categorized as low potential for occurrence.

Hoover's wooly-star was the only listed species known to occur on NPRC prior to this survey. It has been found at over 200 locations (EG\&G Energy Measurements, Inc., 1992b). The presence and distribution of Hoover's wooly-star at NPRC is well documented, and it was only recorded opportunistically during the field surveys. The other two species known to occur on NPRC are holisteria (Hollisteria lanata) and Lost Hills saltbush (Atriplex vallicola), both Category 2 species. Hollisteria was located on NPR-1 during a survey for Hoover's wooly-star in 1991 and Lost Hills saltbush was reported from Section 12G or 13G (T31S, R24E) during a survey conducted in 1988 (EG\&G Energy Measurements, Inc., 1988). Dr. Dean Taylor, one of the botanists conducting the 1988 survey, was contacted regarding the specific location of the reported sighting of Lost Hills saltbush. He stated that the taxonomy of the species was being revised and that it was no longer considered a valid species. Lost Hills saltbush integrates with $A$. cornata and may best be described as a subspecies of that species (Jepson, 1993). For this reason, Lost Hills saltbush was not included in the field surveys.

Kern mallow, San Joaquin wooly-threads, heartscale (Atriplex cordulata) and Recurved larkspur (Delphinium recurvatum) were rated as having a moderate potential for occurrence on NPRC. This determination was based on the amount of preferred habitat and proximity of occurrence. Previous efforts to locate Kern mallow and San Joaquin wooly-threads, the two listed species, have been unsuccessful (EG\&G Energy Measurements, Inc., 1988, 1992b), although valley and foothill grasslands, their preferred habitat, is present on much of NPRC. Recurved larkspur has been located just north of NPR-1 in alkali bottoms on the north side of the California Aqueduct (Stebbins et al., 1992). Heartscale was also collected along the California Aqueduct just east of NPRC (Stebbins et al., 1992) and similar habitat occurs at a few locations along the eastern boundary of NPRC.

The potential for occurrence of the remaining seven species was rated as low. California jewelflower was recorded within 1.5 miles of NPRC along state highway 119 near 
Table 1. List of special status plants species that occur or potentially occur on the Naval Petroleum Reserves in California. Species are ranked by status first, then by preferred habitat within the three rankings of potential for occurrence.

\begin{tabular}{|c|c|c|c|c|c|c|c|}
\hline \multirow[b]{2}{*}{ Species } & \multirow[b]{2}{*}{ Common Name } & \multirow[b]{2}{*}{ Statusa } & \multirow[b]{2}{*}{ Preferred Habitat } & \multicolumn{3}{|c|}{$\begin{array}{c}\text { Potential }^{b} \text { for } \\
\text { Occurrence on } \\
\text { NPRC } \\
\end{array}$} & \multirow[b]{2}{*}{ Sources $^{c}$} \\
\hline & & & & $\mathbf{H}$ & $\mathbf{M}$ & $\mathbf{L}$ & \\
\hline Eremalche kernensis & Kern Mallow & $\mathbf{E}$ & $\begin{array}{l}\text { Chenopod Scrub, Valley \& Foothill } \\
\text { Grassland }\end{array}$ & & $\mathbf{X}^{\mathbf{d}}$ & & $\begin{array}{l}1,2,3 \\
4,5\end{array}$ \\
\hline Lembertia congdonii & $\begin{array}{l}\text { San Joaquin Wooly- } \\
\text { threads }\end{array}$ & $\mathbf{E}$ & $\begin{array}{l}\text { Chenopod Scrub, Valley \& Foothill } \\
\text { Grassland }\end{array}$ & & $\mathbf{x}$ & & $\begin{array}{l}1,2,3 \\
4,5\end{array}$ \\
\hline Caulanthus californicus & California Jewelflower & $\mathbf{E}$ & $\begin{array}{l}\text { Chenopod Scrub, Valley \& Foothill } \\
\text { Grassland }\end{array}$ & & & $\mathbf{X}$ & $\begin{array}{l}1,2,3 \\
4,5 \\
\end{array}$ \\
\hline Eriastrum hooverii & Hoover's Wooly-star & $\mathbf{T}$ & $\begin{array}{l}\text { Alkali Sink Scrub, Valley \& Foothill } \\
\text { Grassland }\end{array}$ & $\mathbf{X}^{\mathbf{d}}$ & & & $3,4,5$ \\
\hline Atriplex vallicola & Lost Hills Saltbush & $\mathrm{C2}$ & Chenopod Scrub & $\mathbf{X}^{\mathbf{d}}$ & & & $1,2,3,4$ \\
\hline Hollisteria lanata & Hollisteria & C2 & $\begin{array}{l}\text { Chenopod Scrub, Valley \& Foothill } \\
\text { Grassland }\end{array}$ & $\mathbf{X}^{\mathbf{d}}$ & & & $\begin{array}{l}1,2,3 \\
4\end{array}$ \\
\hline Atriplex cordulata & Heartscale & C2 & Chenopod Scrub & & $\mathbf{X}$ & & $\begin{array}{l}1,2,3 \\
6\end{array}$ \\
\hline Delphinium recurvatum & Recurved Larkspur & C2 & $\begin{array}{l}\text { Chenopod Scrub, Valley \& Foothill } \\
\text { Grassland }\end{array}$ & & $\mathbf{X}$ & & $\begin{array}{l}1,2,3 \\
6\end{array}$ \\
\hline Atriplex tularensis & Bakersfield Saltbush & C2 & Chenopod Scrub & & & $\mathbf{x}$ & $1,2,3$ \\
\hline $\begin{array}{l}\text { Amsinckia vernicosa } \\
\text { var. furcata }\end{array}$ & Forked Fiddleneck & C2 & Valley \& Foothill Grassland & & & $\mathbf{X}$ & $1,2,3$ \\
\hline Layia leucopappa & Comanche Point Layia & C2 & $\begin{array}{l}\text { Valley \& Foothill Grassland, } \\
\text { Chenopod Scrub }\end{array}$ & & & $\mathbf{x}$ & $1,2,3$ \\
\hline Calochortus striatus & Alkali Mariposa Lily & C2 & Chenopod Scrub, Alkaline Meadows & & & $\mathbf{x}$ & $1,2,3$ \\
\hline $\begin{array}{l}\text { Condylanthus mollis } \\
\text { hispidus }\end{array}$ & Hispid Bird's-beak & C2 & Alkaline Meadows & & & $\mathbf{X}$ & $1,2,3$ \\
\hline Cirsium crassicaule & Slough Thistle & $\mathbf{C 2}$ & Marshes, Swamps & & & $\mathbf{X}$ & $1,2,3$ \\
\hline
\end{tabular}

* C2 - Candidate Category 2; E - Endangered; T - Threatened

b H - High; M - Moderate; L - Low

c Sources:(1) California Department of Fish and Game, 1992a, 1992b; (2) California Native Plant Society, 1988; (3) Federal Register, 1990; (4) EG\&G Energy Measurements, Inc., 1988; (5) Taylor \& Davilla, 1986; (6) Stebbins et al., 1992.

d Presence on NPRC confirmed. 
Valley Acres (Taylor and Davilla, 1986). This population is now extirpated, but the species was included on the list because of the proximity of this historic location. Bakersfield saltbush (Atriplex tularensis) like the other annual Atriplex species occurs in chenopod scrub habitat. This habitat type is rare on NPRC and this particular species appears to have even more stringent requirements because it is only reported from one location. Forked fiddleneck (Amsinckia vernicosa var. furcata) and Comanche Point layia (Layia leucopappa) are found in valley and foothill grasslands, the primary vegetation type on NPRC. However, both of these species are only known from the eastern portion of the southern San Joaquin Valley and their potential for occurrence on NPRC was categorized as low. Alkali Mariposa lily (Calochortus striatus) and the hispid bird's-beak (Cordylanthus mollis hispidus) prefer alkaline meadows. This habitat type is rare on NPRC and the potential for occurrence for these species was rated low. Alkali Mariposa lily is typically found in alkaline meadows and in moist creosote bush scrub at elevations from 2,500 to 4,000 feet (Hickman, 1993). The reason it was included in this survey was that it has been reported from the Buena Vista Lake bed (Personal communication, Russ Lewis, range scientist, Bureau of Land Management). Slough thistle (Cirsium crassicaule) is reported from marshy, swampy areas which is a rare habitat on NPRC. The potential for occurrence for these species is low. All of these species categorized as low potential for occurrence, were maintained on the list as species to watch for during field surveys, but specific survey areas were not identified for any of them.

\subsection{FIELD SURVEYS}

The majority of the habitat for the special status plant species with high or moderate potential for occurrence on NPRC was located along the perimeter of NPRC, particularly the north and east flanks (along the California Aqueduct), and in Buena Vista and Midway valleys (Figure 1). Approximately 7,000 acres of this area was surveyed between April and June, 1993. Suspected populations of the endangered Kern mallow were identified in Sections 9G, 12G (T31S, R24E), and 18H (T32S, R25E). Due to collecting restrictions and the unavailability of a species expert, positive identification was not made. Over 35 new locations of Hoover's wooly-star were recorded on or adjacent to NPRC. Previously unrecorded populations of hollisteria were located in Sections 12C (T31S, R24E), $7 R$, and 30R (T30S, R23E). None of the other special status plant species were observed.

San Joaquin wooly-threads and heartscale may still be found on NPRC. Surveys conducted in late May and June may have been conducted after San Joaquin wooly-threads flowered and senesced. Surveys conducted early on in the growing season were adequate, but later surveys may have been too late to locate the species. Potential habitat for heartscale were surveyed, but it was it was not possible to distinguish heartscale from other annual Atriplex species. 


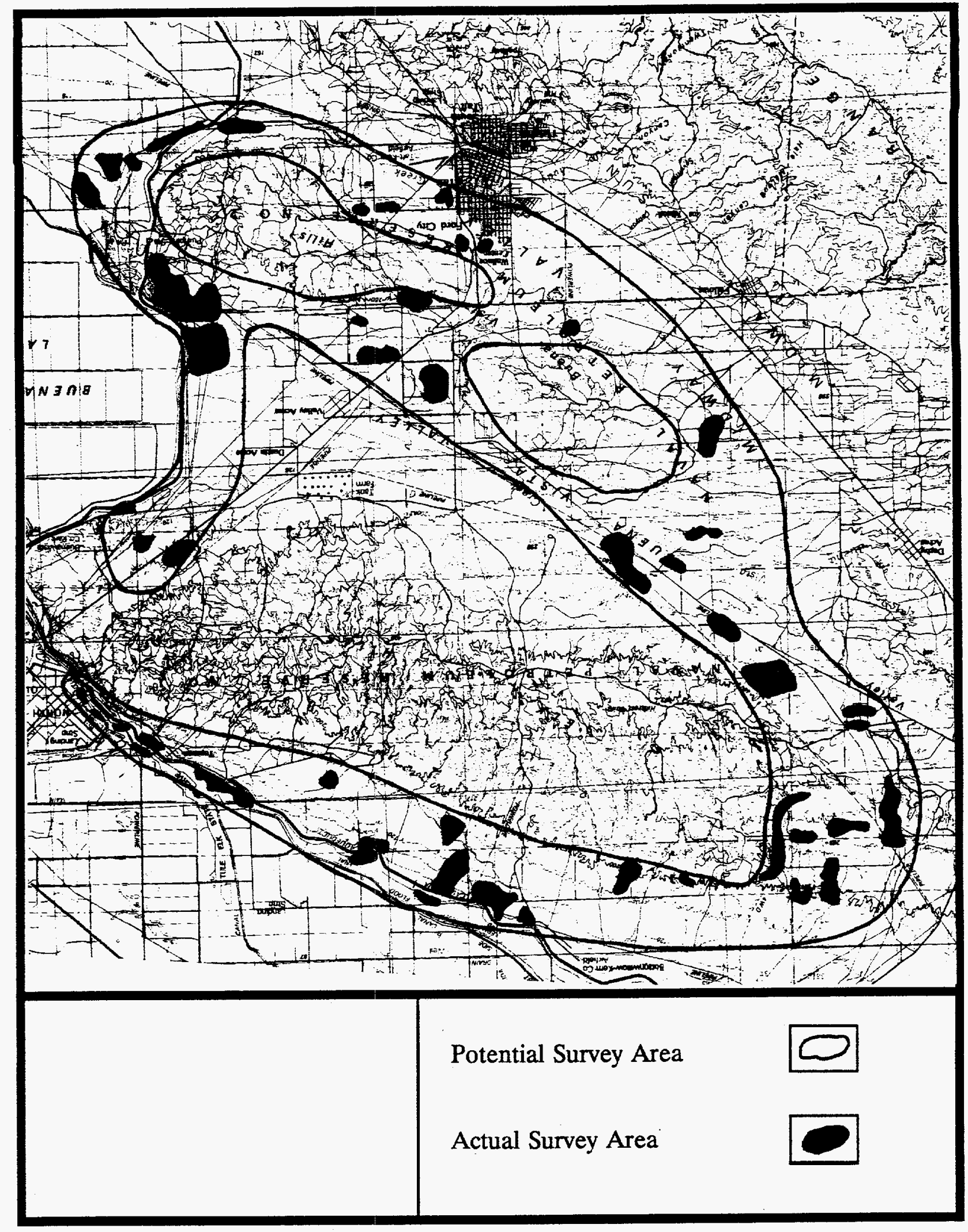

Figure 1. Potential and actual survey areas on or adjacent to the Naval Petroleum Reserves in California. 
The description and distribution for each of the special status plant species are given in the following sections. Plant population site characterization forms for each location of the species encountered on NPRC during the field surveys are included in Appendix C. Site characterization forms for the new locations of Hoover's wooly-star are not included in this report, but have been added to existing files on this species maintained at EG\&G/EM's field office at NPRC.

\subsubsection{Kern mallow (Eremalche kernensis)}

Description

Kern mallow is an annual branching herb, between four and eight inches high, with palmate leaves and white or pale lavender flowers, which are usually in multiples of five.

Taylor and Stebbins (1992) recognize Kern mallow as a valid taxon which can be distinguished from Eremalche parryi by leaf shape and pubescence. However, the taxonomy of Kern mallow was recently reevaluated (Bates, 1992). Bates included $E$. kernensis as a subspecies of $E$. parryi. This taxonomic revision has placed all former $E$. parryi and $E$. kernensis plants that occur in the San Joaquin Valley in $E$. paryi ssp. kernensis. Collections made during this survey have been identified as E. parnyi ssp. kernensis by Dr. Bates. FWS (J. Bartell, personal communication) recognizes this subspecies as the taxon protected as an endangered species.

\section{Distribution}

Kern mallow is found in alkali flats with shadscale and eroded hillsides between 300 to 3,200 feet (Munz and Keck, 1959; Hickman, 1993). It is found in alkali sink scrub and valley grassland habitat. Kern mallow is endemic to the lower San Joaquin Valley and is known to occur in the Temblor Range, in the vicinity of Buttonwillow, McKittrick, and Maricopa. Twisselmann (1967) reported the species to be local on the Belridge Plain and Soda Lake area of San Luis Obispo County, while Bates (1992) noted its occurrence on the Carrizo Plain. Reports of Kern mallow in areas of the San Joaquin Valley outside this range may be based on misidentified occurrences of a related species $E$. parri spp. parryi. The information on the abundance of Kern mallow is somewhat contradictory. CNPS observes that only four of six historic occurrences are extant. NDDB notes that 17 occurrences are extant and two are extirpated.

NPRC: Kern mallow was found on NPR-2 in Section 18H (T32S, R25E) at 330 feet elevation, growing in alkali soils on flat terrain. There was a minimal amount of disturbance due to grazing. The predominant associated plant species were seepweed (Suaeda fruiticosa) and annual Atriplex species. Kern mallow was also found on NPR-1 in Sections 9G and 12G (T31S, R24E) growing in alkali soils on southerly exposed slopes. 


\section{Abundance}

There were approximately 200 plants found in Section $18 \mathrm{H}$ (T32S, R25E), and fewer than 50 plants each at the locations in Sections 9G and 12G (T31S, R24E).

Listing Status

Endangered

\subsubsection{San Joaquin wooly-threads (Lembertia congdonii)}

Description

San Joaquin wooly-threads is an annual herb of the sunflower family (Asteraceae) with branching stems and small yellow disk flowers.

Distribution

Optimal habitat for the San Joaquin wooly-threads consists of moderately alkaline, sandy or clay soils situated on the valley floor, below 1,200 feet. It is known to occur in alkali sink scrub and valley and foothill grassland habitat, including the Carrizo Plain, Elkhorn Plain, and Lost Hills. NDDB notes that there are 24 extant and 10 extirpated populations of San Joaquin wooly-threads.

NPRC: Not found on NPRC. If this species is ever located on or near NPRC it may be along the northern flank of Elk Hills and/or in the Buena Vista Valley. It was not located during the 1993 survey, nor during the 1988 survey (EG\&G Energy Measurements, Inc., 1988).

Abundance

Not known from NPRC.

Listing Status

Endangered

\subsubsection{California jewelflower (Caulanthus californicus)}

\section{Description}

As described in Taylor and Davilla (1988), California jewelflower is an annual herb about 12 inches tall, with several flower branches. It is usually with dry, wavy cut leaves at the base and clasping leaves along the stem. Flowers are translucent white with purple tips. The pods are about $1 / 4$ inch long and sword-shaped. It is similar to $C$. coulteri and $C$. inflatus. The few isolated populations of the later species are found on NPRC. 
Distribution

An historic location of California jewelflower was recorded near NPRC in 1935. Attempts to relocate the population have been unsuccessful. This species is considered unlikely to be present on NPRC.

NPRC: Has not been located on NPRC. It is unlikely that this species occurs on NPRC.

\author{
Abundance \\ Not found on NPRC. \\ $\underline{\text { Listing Status }}$ \\ Endangered
}

\title{
4.2.4 Hoover's wooly-star (Eriastrum hooverii)
}

Description

Hoover's wooly-star is grayish-green annual forb of the phlox family (Polemoniaceae) which is typically 4 to 6 inches tall and often with several branches. The stems are thin and wire-like, and are clothed with loose tufts of wool-like hair. The five-petaled flowers are about 1/4 inch across and persist until July or August.

Distribution

Populations of Hoover's wooly-star extend from near Fresno, California south into the Kettleman Hills, Elkhorn Hills, and Cuyama Valley.

NPRC: Over 300 locations of Hoover's wooly-star are recorded on or adjacent to NPRC. Populations of the species were located in the Buena Vista Hills of NPR-2 during the field surveys conducted in 1993.

Abundance

Several million individuals have been estimated to occur on NPRC.

Listing Status

Threatened

\subsubsection{Lost Hills saltbush (Atriplex vallicola)}

Description

Lost Hills saltbush is a white scurfy looking annual Atriplex species with slender spreading branches. The branches range in length from 1 inch to almost 10 inches. Its leaves are narrow and 2-3 inches long. 


\section{Distribution}

Lost Hills saltbush is found in dry pond and alkaline soils in the southwestern portion of the San Joaquin Valley.

NPRC: This species was reported from the area of Section $12 \mathrm{G}$ or $13 \mathrm{G}$ (T31S, R24E) either on or adjacent to NPR-1. As mentioned in Jepson (1993) it intergrades with $A$. coronata, and should best be considered a subspecies of it.

Abundance

Unknown on NPRC.

Listing Status

Category 2

\subsubsection{Hollisteria (Hollisteria lamata)}

Description

Hollisteria is a slender-stemmed diffuse white-woolly annual (Munz and Keck, 1959). It has well distributed basal leaves and prostrate branches and is between one and eight inches high.

Distribution

Hollisteria occurs in alkali sink scrub and in valley and foothill grasslands. It is commonly found in dry soils, and often occurs on barren slopes in the Temblor range and on the borders of the San Joaquin Valley in the low hills, below 2,500 feet (Munz and Keck, 1959). This species is abundant throughout the Carrizo Plain (Ellen Cypher and Susan Carter, personal communication).

NPRC: Hollisteria was found in Sections 7R and 30R (T30S, R23E) in 1993, and may occur in other areas of NPRC, particularly in the low hills. It was located midslope on a hillside in Section 7R (T30S, R23E) that was slightly disturbed from an oil spill in 1991. The predominant associated plant species were red brome (Bromus rubens) and zorro fescue (Festuca megalura). Hollisteria was also found in Section 12C (T32S, R23E) on NPR-2.

\section{Abundance}

Five plants were observed at the Section $7 R$ (T30S, R23E) population, one individual observed in Section 30R (T30S, R23E), and 100 individuals at the Section 12C (T32S, R23E) population.

Listing Status

Category 2 


\title{
4.2.7 Heartscale (Atriplex cordulata)
}

\section{Description}

This rigid annual herb has coarse stems and is branched from the base. It has sessile, ovate leaves, with flowers that are mixed in small axillary clusters (Munz and Keck, 1959).

\section{Distribution}

Heartscale is typically found on hard, subalkaline soil. This species occurs in alkali sink scrub, alkali meadow, and alkali grassland vegetation associations, and its range includes the Sacramento and San Joaquin Valleys (Munz and Keck, 1959).

NPRC: Has not been located on NPRC during this survey or previous surveys. Habitat for this species would most likely be found in Sections 18H (T32S, R25E) and 12D (T32S, R24E), east of the California Aqueduct, along the north flank, and on dry, exposed, south-facing hills.

Abundance

Not found on NPRC.

Listing Status

Category 2

\subsubsection{Recurved larkspur (Delphinium recurvatum)}

Description

A herb of the crowfoot family (Ranunculaceae). It has woody roots, red to purple stems, and white to blue petals (Munz and Keck, 1959).

Distribution

Recurved larkspur occurs in valley and foothill grasslands and alkali sink scrub, such as Soda Lake. It is widespread in the Carrizo Plain. The NDDB lists 23 extant populations and one extirpated population of recurved larkspur. It has been collected north of NPR-1 along the California Aqueduct.

NPRC: Not located on NPRC. The best potential habitat for recurved larkspur is along the northern boundary of NPR-1. That area was surveyed in 1993 with negative results. It is unlikely that this species occurs on NPRC.

\author{
Abundance \\ Not known from NPRC. \\ Listing Status \\ Category 2
}




\subsubsection{Bakersfield saltbush (Atriplex tularensis)}

Description

Bakersfield saltbush is an erect annual herb 4 to 30 inches high. It has a whitish green appearance and the upper leaves are red tipped.

Distribution

Bakersfield saltbush is found in alkaline soils. It is associated with saltgrass (Distichlis stricta), scratch grass (Sporobolus asperiflorus) and iodine bush (Allenrolfia occidentalis). It is known from locations south of Bakersfield, specifically the Kern lake bed.

NPRC: Not found on NPRC. Preferred habitat for Bakersfield saltbush (i.e., alkali sink scrub, alkali meadow, or alkali grassland) is not found on NPRC.

Abundance

Not found on NPRC.

Listing Status

Category 2

\subsubsection{Forked fiddleneck (Amsinckia vemicosa var. furcata)}

Description

Forked fiddleneck is an annual herb ranging from 12 to 20 inches high. The flower is orange, about $1 / 2$ inch in width.

Distribution

Forked fiddleneck is known rarely from western Fresno Co., San Luis Obispo Co. and Kern Co. at elevations from 150 to over 3,000 feet.

NPRC: Not known from NPRC. Forked fiddleneck is known from foothill grasslands. Known populations of this plant does not occur in the vicinity of NPRC, and it is unlikely that it occurs on NPRC.

Abundance

Not known from NPRC.

Listing Status

Category 2 


\title{
42.11 Comanche Point layia (Lavia leucopappa)
}

Description

Comanche Point layia is an annual herb. It reaches 20 inches in height, occasionally branches, but most frequently a single stem. The leaves are fleshy and the leaves at the base are dissected. The flower is white around the edge with a yellow center.

Distribution

Comanche Point layia is found on open slopes in the valley grasslands in the Tejon Hills of the southern end of the San Joaquin Valley.

NPRC: Not known from NPRC. Comanche Point layia is known from the base of the Tejon hills south of Arvin. No known populations occur in the vicinity of NPRC, and it is unlikely that it occurs on NPRC.

\author{
Abundance \\ Not known from NPRC. \\ Listing Status \\ Category 2
}

\subsubsection{Alkali Mariposa lily (Calochortus striatus)}

Description

Alkali Mariposa lily is four to eighteen inches high, has an erect stem, basal leaves, and lavender flowers.

Distribution

Alkali Mariposa lily occurs in alkali sink scrub and alkaline meadow habitats between 2,500 to 4,300 feet in elevation. Optimal habitat for this species includes springs and washes in alkaline soils. The NDDB reports 31 extant populations and one extirpated population.

NPRC: Not found on NPRC.

\section{Abundance}

Not known from NPRC. This species appears to be located at higher elevations and it is unlikely to be found on NPRC. It has been reported in the Buena Vista Lake playa (Russ Lewis, personal communication). The only possible areas this species might be found is in areas of seasonal streams, such as the Buena Vista Valley.

\section{Listing Status}

Category 2 


\subsubsection{Hispid bird's-beak (Cordylanthus mollis hispidus)}

Description

Hispid bird's-beak has a bristly, hairy appearance. It is commonly 4 to 15 inches high, grayish-green, and often tinged purple. It has numerous branches which are terminated with a cluster of small white flowers.

Distribution

Hispid bird's-beak is found in saline marshes and flats from Solano Co. on the north, south to Kern Co. (California Department of Fish and Game, 1992b).

NPRC: Not known from NPRC.

Abundance

Not known from NPRC. Possible habitat for this species does not occur on NPRC.

$\underline{\text { Listing Status }}$

Category 2

\subsubsection{Slough thistle (Cirsium crassicaule)}

\section{Description}

Slough thistle is an annual or biennial herb that grows to heights of 3 to 10 feet. It is usually a single stem and appears cobwebby due to an abundance of soft white hairs. It has a silvery-green appearance with sharp, prickly leaves. Flowers are born at the apex of the stem and are pale rose-purple.

Distribution

Slough thistle is found rarely from freshwater marshes in the southern San Joaquin Valley and San Joaquin River at elevations of less than 350 feet.

NPRC: Not known from NPRC. Slough thistle prefers habitat similar to Bakersfield saltbush, as well as more moist habitats such as marshes and swamps. This type of habitat occurs just north of NPR-1 in the Buena Vista Slough, but not on NPRC.

Abundance

Not known from NPRC.

Listing Status

Category 2 


\section{DISCUSSION AND RECOMMENDATIONS}

The occurrence of Kern mallow on NPRC was a significant finding of the 1993 survey. The specimens collected from Sections 18H (T32S, R25E) and 12G (T31S, R24E) were identified as Eremalche parryi ssp. kernensis by Dr. David Bates, the taxonomic expert on this genus. FWS considers this taxon to be synonymous with $E$. kernensis, which is protected under the Endangered Species Act (J. Bartel, personal communication). Under this new taxonomic position the distribution of Kern mallow encompasses Kern, San Luis Obispo, Santa Barbara and Tulare Counties, whereas before its distribution was considered to be limited to the region around McKittrick, and a population near Maricopa. It occurs in a range of habitats on NPRC, including the bottomlands in Section 18H (T32S, R25E) and open hillsides in the low hills and uplands of NPR-1.

There are several recommended actions for the future conservation and protection of Kern mallow. First, information gathered on this species should be forwarded to FWS, so that it may be included in the current consultation. Any additional information obtained on the ecology or distribution of Kern mallow should also be forwarded to FWS as well as the NDDB, for use in developing management and conservation programs for recovery of the species. The second recommended action is to continue to include Kern mallow in the preactivity survey process. If an activity is proposed for an area where Kern mallow is known to occur, or if the species is located during the preactivity survey, the area should be avoided if possible. EG\&G/EM staff conducting preactivity surveys should be trained in the identification of Kern mallow and become familiar with the habitat of known populations of the species. The final recommendation is to monitor known populations of Kern mallow over time to document its presence. Monitoring should be done in a manner that will compliment similar monitoring programs conducted on this species by other conservation groups.

Other than Hoover's wooly-star, San Joaquin wooly-threads is the only other listed species that warrants further consideration at this time. The majority of the habitat for this species on NPRC has been surveyed and it has not been found. Surveys conducted during the later part of May and the first part of June in 1993 may have been conducted after senescence. However, surveys conducted in April and early May in 1993 and the surveys conducted in 1988 have failed to locate this species on NPRC. It is recommended that this species, like Kern mallow, be included in preactivity surveys and that staff conducting surveys receive training on identification of San Joaquin wooly-threads and that they become familiar with areas where it might occur on NPRC.

Heartscale and hollisteria are the only Category 2 species that warrant further action. Heartscale occurs along the California Aqueduct near the eastern boundary of NPR1. Annual Atriplex species were found and collected during the 1993 survey, but it was difficult to determine if it was $A$. cordulata or $A$. coronata a species which is similar in appearance. A species expert may be required to differentiate heartscale from the complex of annual Atriplex species found near the eastern boundary of NPRC. Positive identification of current collections of Atriplex species will be made to determine if any are heartscale.

Hollisteria has been reported to occur abundantly on the Carrizo Plain, but 
populations on NPRC appear to be scattered and in low densities. It is recommended that hollisteria be included in the preactivity survey process and that known populations be avoided if possible. The three known populations on NPRC should also be monitored to document population status.

Any information on the distribution or ecology of any of the listed or candidate species should be sent to FWS, so that information obtained at NPRC might be considered in preparing reports for the listing or delisting of plant species. The information should also be sent to NDDB so that other researchers are informed of the distribution of listed and candidate plant species on NPRC.

Completion of the surveys in 1993 marks the third year that surveys have been conducted on NPRC for either listed or candidate plant species. Each of the three surveys were conducted under different environmental conditions. Annual precipitation, which is probably the factor affecting annual plant occurrence and abundance more than any other factor, varied in both amount and distribution. The surveys conducted in 1993 provided an assessment of the occurrence of 14 special status plant species on NPRC under near or slightly above average growing season precipitation. The amount of precipitation in 1988 and 1991 was different than was experienced in 1993 as was the distribution of the rainfall. The information obtained from these surveys has provided a sound basis for determining the potential for occurrence of these species on NPRC. Although all of NPRC has not been surveyed, their presence or absence can be determined with a higher level of confidence now, than could be ascertained prior to conducting the surveys. 


\section{REFERENCES}

Bates, D. M. 1992. Gynodioecy, endangerment, and status of Eremalche kernensis (Malvaceae). Phytologia 72(1): 48-54.

California Department of Fish and Game. 1992a. Designated endangered, threatened, or rare plants and candidates with official listing dates. Natural Heritage Division, Endangered Plant Program. 6 pp.

California Department of Fish and Game. 1992b. Natural Diversity Database. Sacramento, California.

California Native Plant Society. 1988. Inventory of rare and endangered vascular plants of California. J. P. Smith, Jr., and K. Berg, eds. Special Publication No. 1, 4th ed. $168 \mathrm{pp}$.

EG\&G Energy Measurements, Inc. 1988. The Occurrence and status of candidate species listed by the U.S. Fish and Wildlife Service on Naval Petroleum Reserve \#1, Kern County, California. EG\&G Energy Measurements Report EGG 10617-2015, Santa Barbara Operations, Goleta, Calif. 62 pp.

EG\&G Energy Measurements, Inc. 1992a. Endangered species program, Naval Petroleum Reserves in California, annual report FY91. EG\&G Energy Measurements Report EGG 10617-2131, Santa Barbara Operations, Goleta, Calif. 71 pp.

EG\&G Energy Measurements, Inc. 1992b. Endangered species program, Naval Petroleum Reserves in California, annual report FY92. EG\&G Energy Measurements Report EGG 10617-2166, Santa Barbara Operations, Goleta, Calif. 44 pp.

Federal Register. 1990. Endangered and threatened wildlife and plants: review of plant taxa for listing as endangered or threatened species; notice of review, part IV. U.S. Department of the Interior, Fish and Wildlife Service. 50 CFR part 17.

Hickman, J.C., editor. 1993. The Jepson Manual, Higher Plants of California. University of California Press, Berkeley, California. 1,400 pp.

Munz, P. A., and D. D. Keck. 1959. A California flora, with supplement (1968). University of California Press, Berkeley. 224 pp.

Nelson, J. R. 1987. Rare plant surveys: techniques for impact assessment. Pages 159-166 in T. Elias, ed. Conservation and management of rare and endangered plants. California Native Plant Society, Sacramento, Calif. 630 pp.

Stebbins, J. C., T. E. Mallory, W. O. Trayler, and G. W. Moise. 1992. Botanical resource report, California Aqueduct - San Joaquin field division, Department of Water Resources. California State University, Fresno. 28 pp. + append. 
Taylor, D. W., and W. B. Davilla. 1986. Status survey for three plants endemic to the San Joaquin Valley, California. Unpublished report to U.S. Fish and Wildlife Service, Sacramento, Calif. 131 pp.

Taylor, D. W., and J. Stebbins. 1992. Flora of the San Joaquin Valley: endemism and endangerment to status (abstract only). Pages 384-385 in D. Williams, S. Byrne, and T. Rado, eds. Proceedings of a 1987 Conference on Endangered and Sensitive Species of the San Joaquin Valley, California. California Energy Commission, Sacramento.

Twisselmann, E.C. 1967. A flora of Kern County. California Wasmann Journal of Biology 25:1-395.

U.S. Fish and Wildlife Service. 1989. Notice of proposed endangered or threatened status for five plants from the southern San Joaquin Valley. Letter from Gail C. Kobetich (Ref. Lr25P2) to EG\&G Energy Measurements, Inc. 


\section{APPENDIX A}

CALIFORNIA NATIVE SPECIES FIELD SURVEY FORM 


\section{California Native Species Field Survey Form}

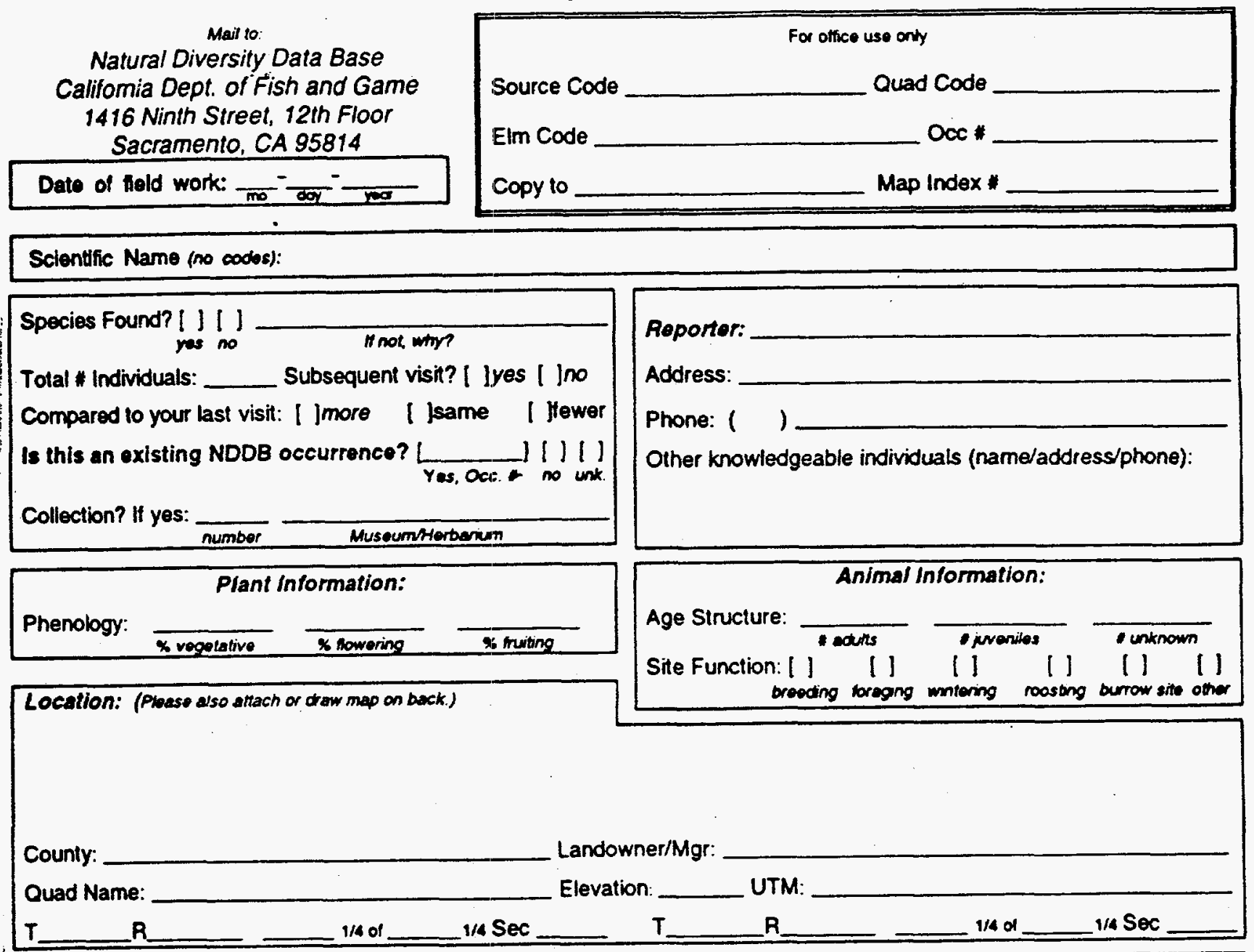

Habltat Description: (Plant communibies, dominents, essociates, substrate/soils, espectstope)

Other rero spp.?

Sito Information: Current/surrounding land use:

Visible disturbances, possible threats:

Overall site quality: [ ]Excellent [ ]Good I ]Fair I ]Poor Comments:

Dotermination: (Chack one or more, sti in the blanks)

Koyed in a site relerence:

Compared with specimon housed at:

Compared with photo/ctawing in:

Oy enother person (name)

Other:

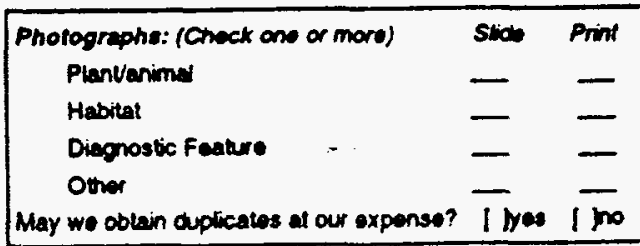




\section{APPENDIX B}

PLANT POPULATION SITE CHARACTERIZATION FORM - NPRC 


\section{PLANT POPULATION SITE CHARACTERIZATION FORM - NPRC}

Species:

Map Attached: Yes - No

Recorder(s):

Date:

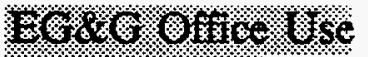

Nev. I. siation: Yes - No

STI. No:

Siro Mapped: Yes - No
Quad Name:

Township:

Slope (degrees):

Description of Location:
Elevation:

Township Code: to Aspect: N, S, E, W, Flat

. (ft)

of $1 / 4$ : $1 / 4$

$\begin{array}{lll}\begin{array}{l}\text { Physiography: } \\ \text { Wash }\end{array} & \begin{array}{l}\text { Topog. Position: } \\ \text { Crest }\end{array} & \begin{array}{l}\text { Micro. Relief: } \\ \text { Swale }\end{array} \\ \text { - Drainage } & \text { - Upper-Slope } & \text { - Raised Ground } \\ \text { - Ridge } & \text { - Mid-Slope } & \text { - Undulating } \\ \text { - Flats } & \text { _ Lower-Slope } & \text { - Level } \\ \text { - Slope } & \text { Bottom } & \text { - Slope }\end{array}$

Dist. Type:

Alluvial

Fire
Mechanical
Grazing
Other: None
No. Individuals: Population Area:

Tot. if known
-110
$-11-50$
$-51-100$
$-101-500$
$-501-1,000$
$-1,001-5,000$
$-5,001-10,000$
$->10,000$

Abundant Species

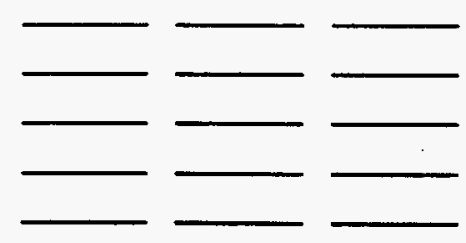

Comments: $10-100 \mathrm{~m}^{2}$
Est. \% Cover: Plant

Litter Bare Ground Cryptogams

$-1-5 \mathrm{~m}^{2}$ $5-10 \mathrm{~m}^{2}$ $100 \mathrm{~m}^{2}-1$ ha $>1$ ha $(2.5 \mathrm{ac})$
Est. \% Rel. Cover:

Dist. Level: Extreme

Moderate

Slight None Shrub

Grass
Composite Soil Sample Collected (5 random locations, $500 \mathrm{~g} \mathrm{ea}$ )
(4 letter codes)

Common Species

Rare Species
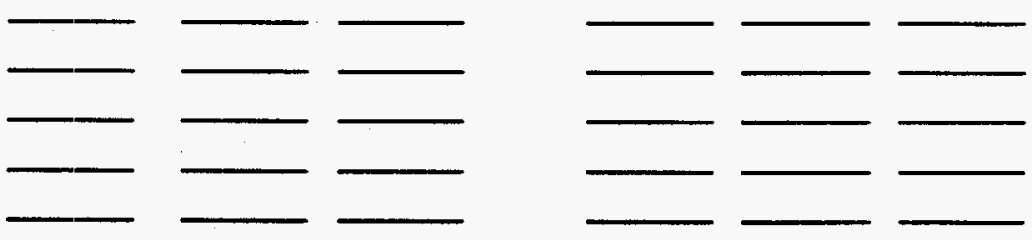


\section{APPENDIX C}

PLANT POPULATION SITE CHARACTERIZATION FORMS FOR PLANTS FOUND ON NPRC DURING 1993 FIELD SURVEYS 


\section{PLANT POPULATION SITE CHARACTERIZATION FORM - NPRC}

Species:ERKE (4 letter code)

Map Attached: Yes

Recorder(s): D. Anderson, B. Cypher, G. Holmstead

E6.80. Offer Ifse

New lacanisn: Yes

01

Date: $5 / 4 / 93$

SHo .raped: Yes

Species Name: Eremalche kernensis

Common Name: Kern mallow

Quad Name: Mouth of Kern

Elevation: 330' to

(ft)

Township: 32S Range: $25 E$ Section: 18 Township Code: $\underline{\text { H }}$ 1/4: $\underline{\text { SE }}$ of 1/4:

Slope (degrees): 0 Aspect: Flat

Description of Location. Approximately $1 / 2$ miles mest of Lake Station road, approximately

$100 \mathrm{~m}$ north of "Atriplex forest" (A. lentiformis)

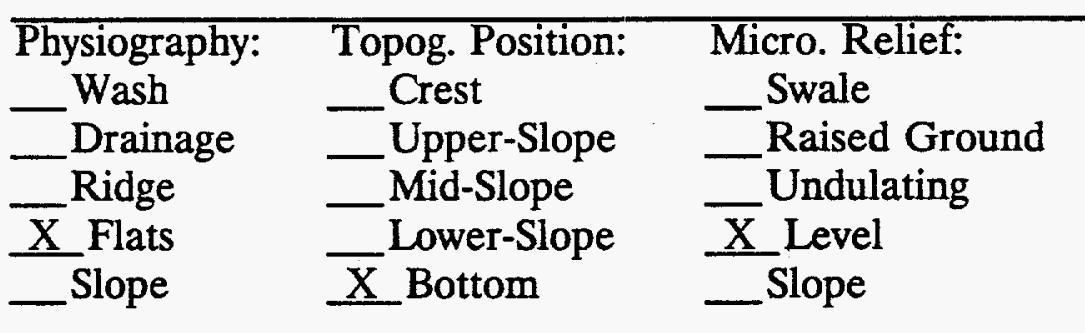

Dist. Type: Dist. Level:

No. Individuals: Population Area:

Tot. if known
$-1-10$
$-11-50$
$-51-100$
$\mathrm{X} 101-500(\mathbf{2 0 0})$
$-501-1,000$
$-1,001-5,000$
$-5,001-10,000$
$->10,000$

$-<1 \mathrm{~m}^{2}$

$1-5 \mathrm{~m}^{2}$

$5-10 \mathrm{~m}^{2}$ $10-100 \mathrm{~m}^{2}$

$\mathrm{X} 100 \mathrm{~m}^{2}-1 \mathrm{ha}$ $>1$ ha $(2.5 \mathrm{ac})$
Alluvial

Fire

$\bar{X}$ Mechanical

$X$ Grazing Other:

Sile No: ERKE - 


\section{SITE NO. : ERKE - 01}

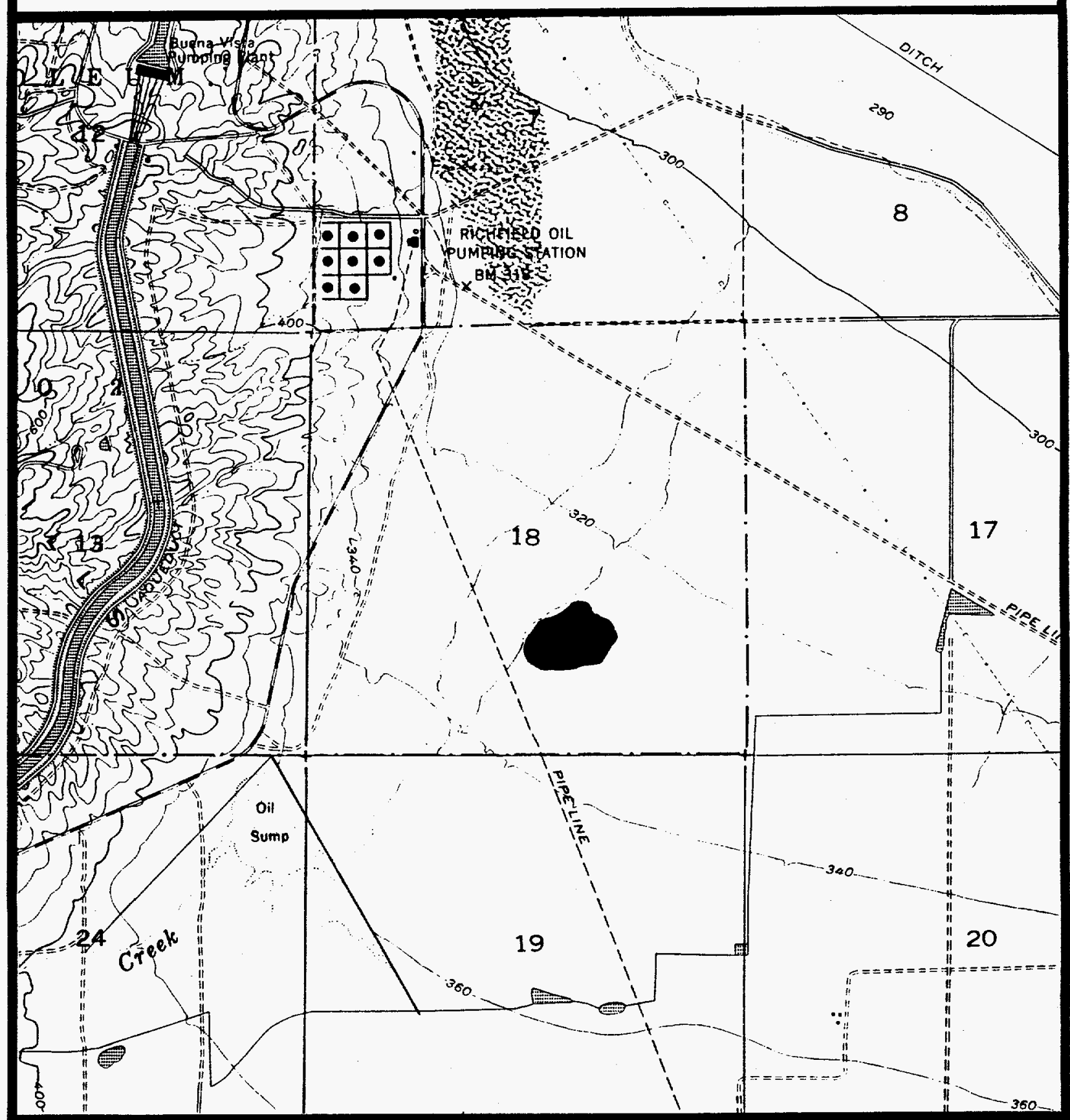

Quadrangle: Mouth of Kern

Township: 32S

Range: 25E

Section: $18 H$ 


\section{PLANT POPULATION SITE CHARACTERIZATION FORM - NPRC}

Species:ERKE (4 letter code)

Map Attached: Yes

Recorder(s): Kristie Hammer

Date: $\quad 5 / 9 / 93$

Species Name: Eremalche kernensis

Common Name: Kern Mallow

Quad Name: Taft

(ft)

Township: 31S Range: 24E Section: 9 Township Code: $\mathbf{\text { G }}$ 1/4: SE of 1/4: SE Slope (degrees): $7-8$ Aspect: $S$

Description of Location-By wells 78 and 87

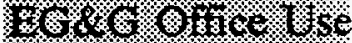

New I- .eation: Yes

Sito No: ERKE - 02

Sile Uapred: Yes to $\underline{700}$
Physiography: Topog. Position:

Wash
- Drainage
- Ridge
Flats
$\bar{X}$ Slope

No. Individuals:

— Tot. if known

$1-10$

$\mathrm{X} 11-50$

$51-100$

$101-500$

$501-1,000$

$1,001-5,000$

$5,001-10,000$

$>10,000$
Micro. Relief:

_ Swale

_ Raised Ground Undulating Level

$\bar{X}$ Slope
Dist. Type: Alluvial Fire X Mechanical Grazing Other: None 
SITE NO. : ERKE - 02

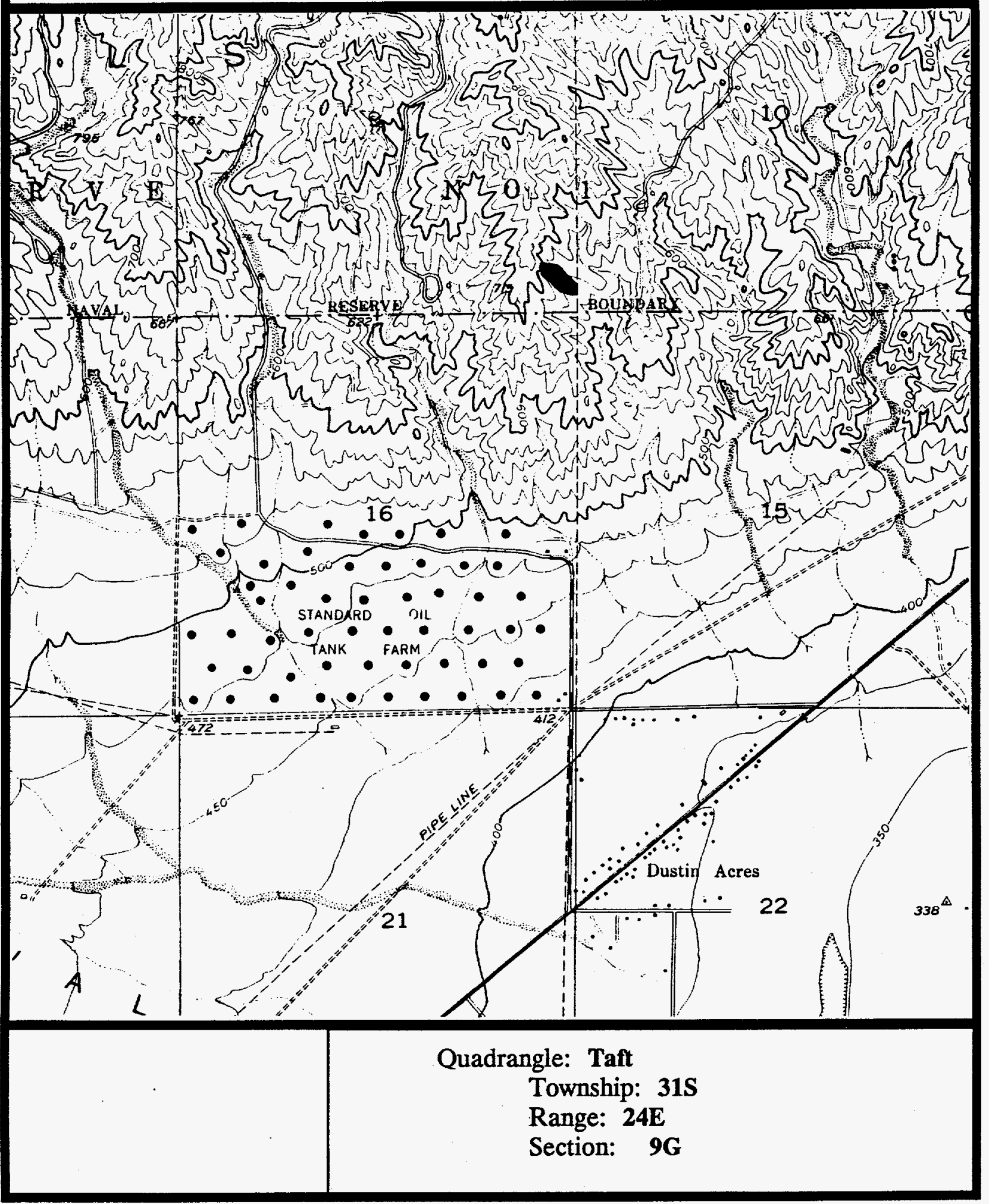


PLANT POPULATION SITE CHARACTERIZATION FORM - NPRC

Species:ERKE (4 letter code)

Map Attached: Yes

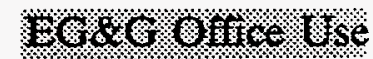

Recorder(s): Kristie Hammer

A.). I.

Date: $\quad 5 / 9 / 93$

Species Name: Eremalche kernensis

SII. No: ERKE - 03

Sire Uapped: Yes - No

Common Name: Kern mallow

Quad Name: Mouth of Kern

Elevation: 450 to 500 (ft)

Township: 30S Range: 24E Section: 12 Township Code: G 1/4: SW of $1 / 4:$ NE Slope (degrees): $31 \mathrm{~S}$ Aspect: $\mathbf{S}$

Description of Location:Narth of L119; SE 12G

Physiography: Topog. Position: Micro. Relief: Dist. Type: Dist.

Level:

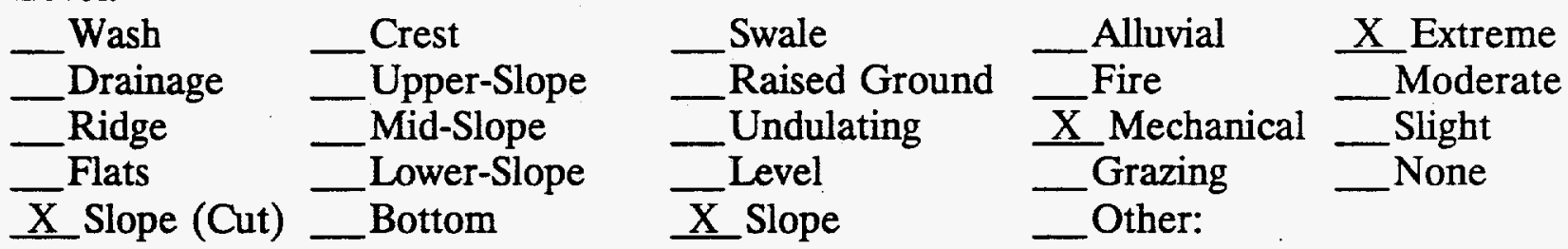

No. Individuals: Population Area: $\quad$ Est. \% Cover: $\quad$ Est. \% Rel. Cover:

Tot. if known
$\mathrm{X} 1-10$
$-11-50$
$-51-100$
$-101-500$
$-501-1,000$
$-1,001-5,000$
$-5,001-10,000$
$->10,000$

$$
\begin{aligned}
& \bar{X}^{<} 1 \mathrm{~m}^{2} \\
& -5-10 \mathrm{~m}^{2} \\
& -10-100 \mathrm{~m}^{2} \\
& -100 \mathrm{~m}^{2}-1 \mathrm{ha} \\
& ->1 \mathrm{ha}(2.5 \mathrm{ac})
\end{aligned}
$$

_Plant

Litter

Bare Ground

Cryptogams

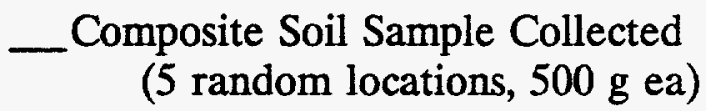

Shrub Grass

Forb
Abundant Species

ATPH

ATCO

Comments:

(4 letter codes)

Common Species ATPO
Rare Species 
SITE NO. : ERKE - 03

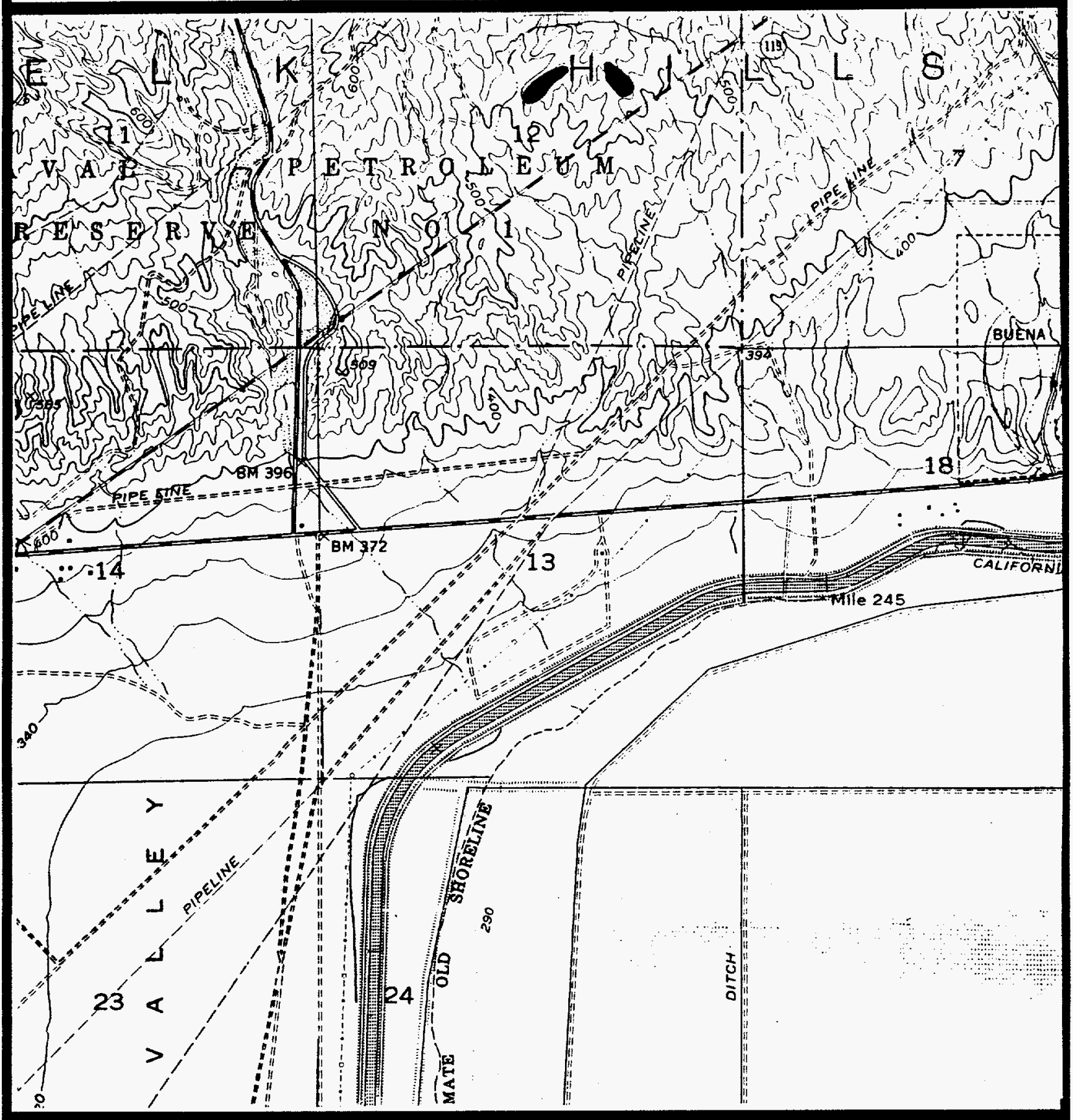

Quadrangle: Mouth of Kern Township: 30S

Range: $24 \mathrm{E}$

Section: 12G 


\section{PLANT POPULATION SITE CHARACTERIZATION FORM - NPRC}

Species: HOLA (4 letter code)

Map Attached: Yes

Recorder(s): Gary Holmstead WOB.8. OTIise Irse

1.1. L 8. this: Yes

Sic No: HOLA - 01

Date: $4 / 27 / 93$

Stic Wapied:

Species Name: Hollisteria lanata

Common Name: Hollisteria

Quad Name: Taft

Elevation: 820

to

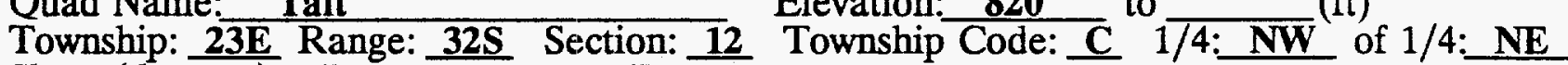
Slope (degrees): Flat Aspect: Flat

Description of Location. Approximately $50 \mathrm{~m}$ south of well 22-12C, NPR-2

Physiography: Topog. Position: Micro. Relief: Dist. Type: Dist. Level:

\begin{tabular}{|c|c|c|}
\hline Wash & Crest & Swale \\
\hline age & _Upper-Slope & Raised Ground \\
\hline $\mathrm{Ri}$ & Mid-Slope & $\bar{X}$ Undulating \\
\hline Fl & Lower-Slope & Level \\
\hline Slope & X Bottom & _Slope \\
\hline
\end{tabular}

Alluvial

- Fire

- Mechanical Grazing Other:

$\underline{\mathrm{X}}$ None
No. Individuals: $\quad$ Population Area:

Tot. if known 1-10 $11-50$

X $51-100$

101-500

$501-1,000$

$1,001-5,000$

$5,001-10,000$

$>10,000$

Abundant Species

BRRU

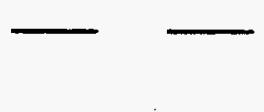

$-<1 \mathrm{~m}^{2}$ $1-5 \mathrm{~m}^{2}$

X $5-10 \mathrm{~m}^{2}$

$10-100 \mathrm{~m}^{2}$ $100 \mathrm{~m}^{2}-1$ ha $>1$ ha $(2.5 \mathrm{ac})$
Est. \% Cover:

80 Plant

10 Litter

10 Bare Ground

0 Cryptogams
Extreme Moderate

Slight

$\bar{X}$ None

.

Est. \% Rel. Cover:

$\mathbf{5}$ Shrub

5 Forb

Composite Soil Sample Collected

(5 random locations, $500 \mathrm{~g} \mathrm{ea}$ )

(4 letter codes)

Common Species

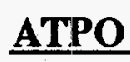

FEME

SCBA

Comments: Approximately 100 plants. Thick vegetation! Mostly red brome.

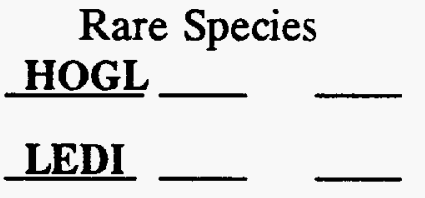

FORM NO. 3530-1 REV: MARCH 19 SUPERSEDES: NE 
SITE NO. : HOLA - 01

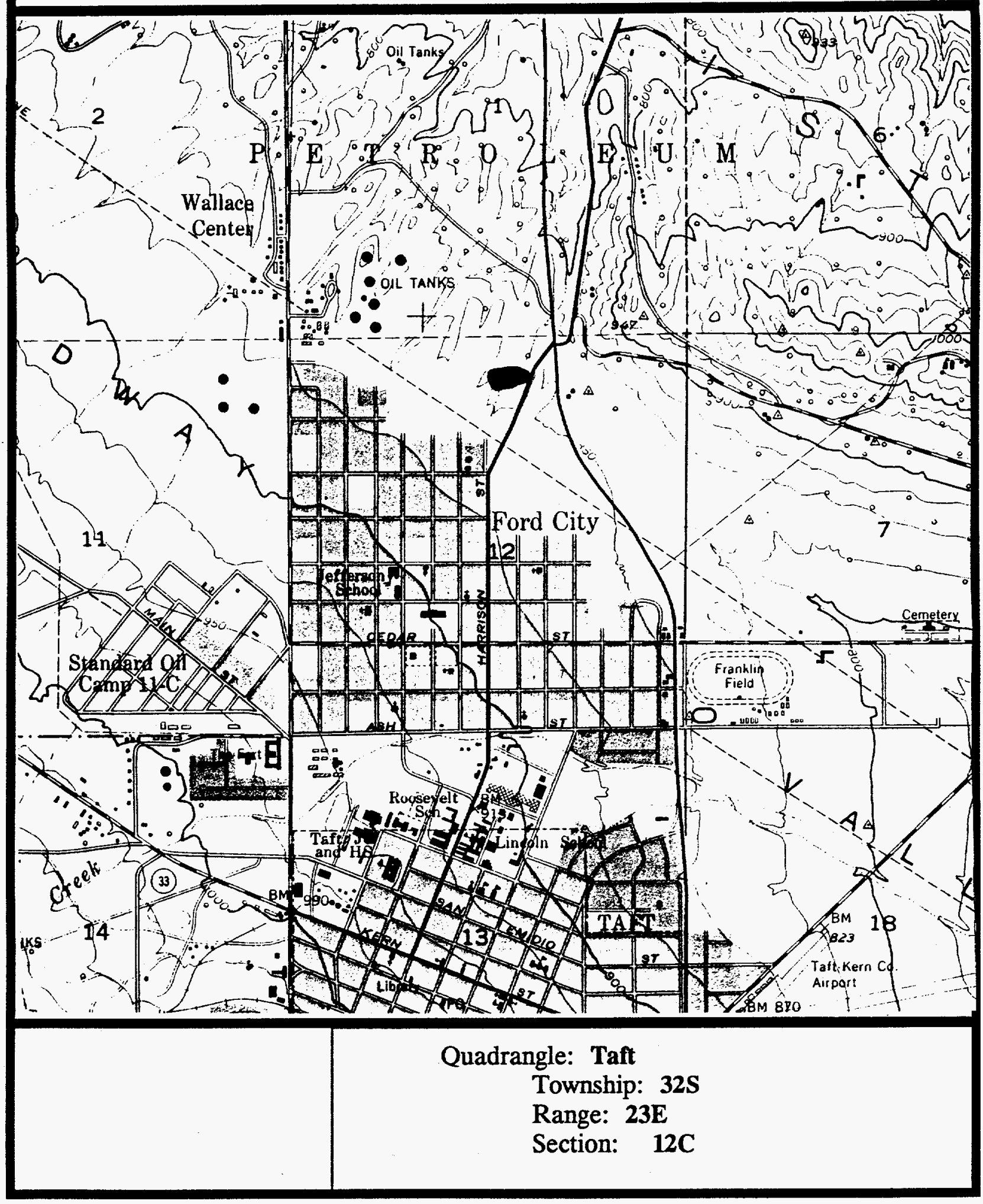


Species: HOLA (4 letter code)

Map Attached: Yes

Recorder(s): David Anderson

Date: $\quad 4 / 29 / 93$

He\&.6 OHee Use

Tew I

Sire No: HOLA - 02

Sire Uapped: Yes - No

Species Name: Hollisteria lanata

Common Name: Hollisteria

Quad Name: West Elk Hills

Elevation: 1240 to 1260

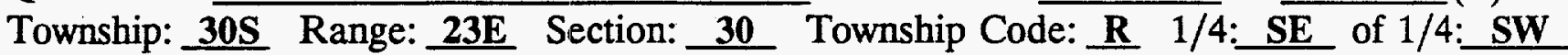
Slope (degrees): 2 Aspect: $\mathbf{S}$

Description of Location: In saddlle alng gentle rolling hills on south slope

of Elk Hills

Physiography: Topog. Position: Micro. Relief: Dist. Type: Dist. Level:

Alluvial

Fire Mechanical Grazing Other:

$\overline{\mathrm{X}}$ None
Extreme Moderate

Slight

X None
_Wash

Drainage $\underline{X}$ Upper-Slope

$X$ Ridge

Flats

Slope
Mid-Slope Lower-Slope Bottom \begin{tabular}{l} 
Swale \\
Raised Ground \\
Z Undulating \\
$\overline{\mathrm{X}}$ Level \\
\hline Slope
\end{tabular}

Est. \% Cover:

70 Plant

Population Area:

1 Tot. if known
$-1-10$
$-11-50$
$-51-100$
$-101-500$
$-501-1,000$
$-1,001-5,000$
$-5,001-10,000$
$->10,000$

Abundant Species

BRRU FEME

Comments:
15 Litter

15 Bare Ground

0 Cryptogams

$1<1 \mathrm{~m}^{2}$

$1-5 \mathrm{~m}^{2}$

X $5-10 \mathrm{~m}^{2}$ $10-100 \mathrm{~m}^{2}$ $100 \mathrm{~m}^{2}-1$ ha _ 1 ha $(2.5 \mathrm{ac})$

_ Composite Soil Sample Collected

(5 random locations, $500 \mathrm{~g} \mathrm{ea}$ )

5 Shrub

80 Grass

15 Forb

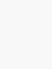

el. Cover: 


\section{SITE NO. : HOLA - 02}

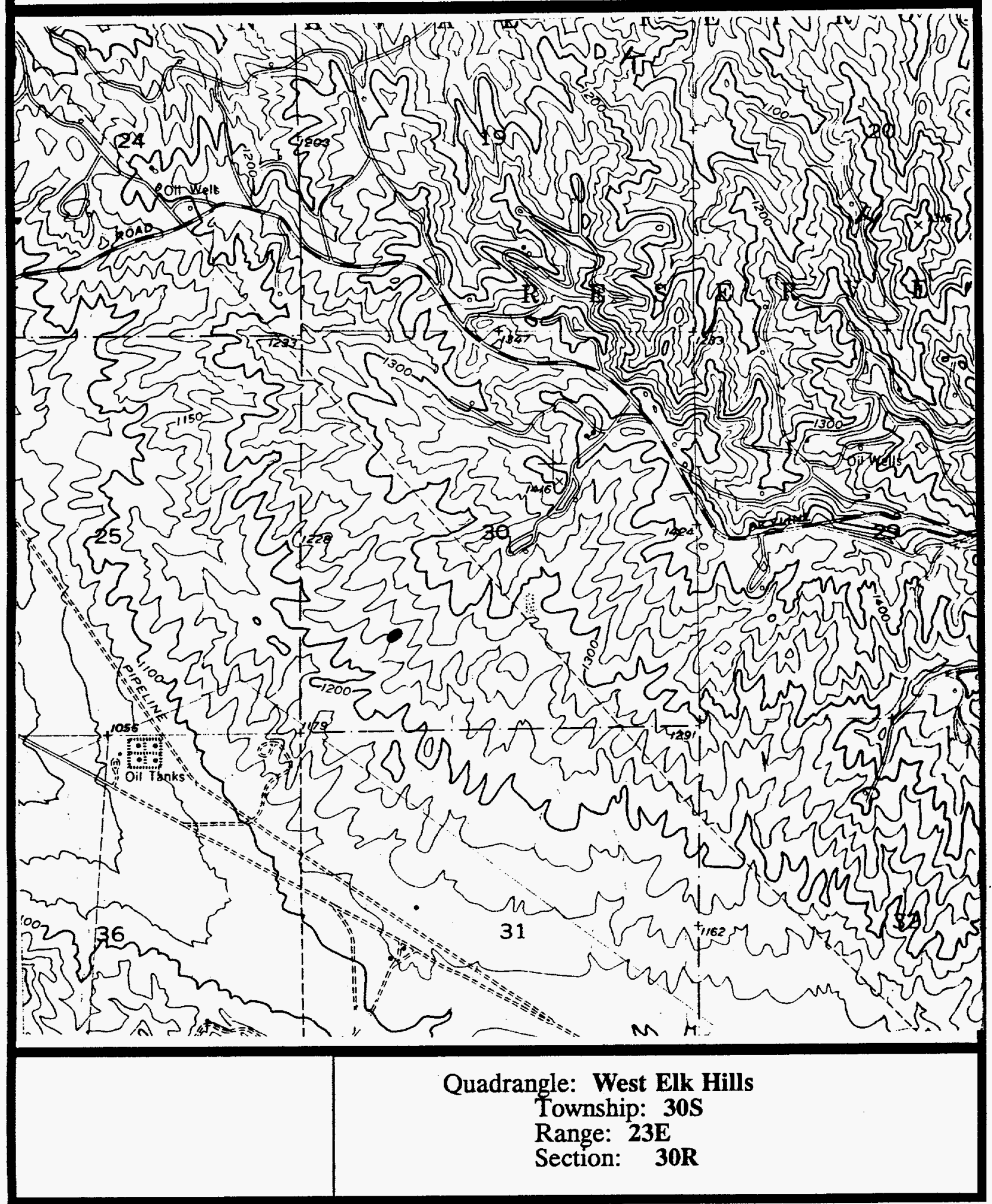




\section{PLANT POPULATION SITE CHARACTERIZATION FORM - NPRC}

Species: HOLA (4 letter code)

Map Attached: Yes

Recorder(s): Gary Holmstead

Date: $\quad 5 / 11 / 93$

Species Name: Hollisteria lanata

Common Name: Hollisteria

Quad Name: West Elk Hills

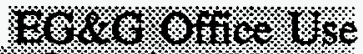

Nev L8cantion: Yes

Site No: HOLA - 03

Sile Mapped: Yes - No

Township: 30S Range: $23 \mathrm{E}$ Section: 7 Township Code: $\underline{\mathbf{R}}$ 1/4: $\mathbf{N} \overline{\mathbf{W}}$ of $1 / 4: \underline{\mathrm{SE}}$ Slope (degrees): $16 \quad$ Aspect: W

Description of Location. On hillside, south of large pipeline, abaut $80 \mathrm{~m}$ S/SE

of Well 354-7R

Physiography: Topog. Position: Micro. Relief: . Dist. Type: Dist. Level:

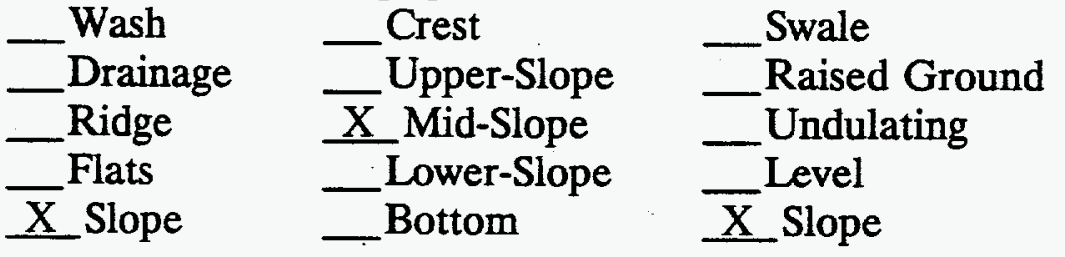

\begin{tabular}{|c|c|}
\hline Alluvial & Extreme \\
\hline & Moderate \\
\hline Mechanical & $\mathrm{X}$ Slight \\
\hline Oth & \\
\hline
\end{tabular}

No. Individuals: Population Area:

Tot. if known
$\times 1-10$
$-11-50$
$51-100$
$101-500$
$501-1,000$
$1,001-5,000$
$5,001-10,000$
$>10,000$

Abundant Species

BRRU FEME

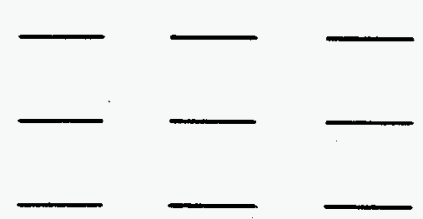

$<1 \mathrm{~m}^{2}$

$\overline{\mathrm{X}} 1-5 \mathrm{~m}^{2}$

$5-10 \mathrm{~m}^{2}$ $10-100 \mathrm{~m}^{2}$ $100 \mathrm{~m}^{2}-1$ ha

— $>1$ ha $(2.5 \mathrm{ac})$
Est. \% Cover: 60 Plant

10 Litter

20 Bare Ground

10 Cryptogams
Est. \% Rel. Cover:

2 Shrub

88 Grass

10 Forb

\section{Composite Soil Sample Collected (5 random locations, $500 \mathrm{~g} \mathrm{ea}$ )}

Comments: Sampled as part of Hover's wooly-star site characterization - Site \#269 


\section{SITE NO. : HOLA - 03}

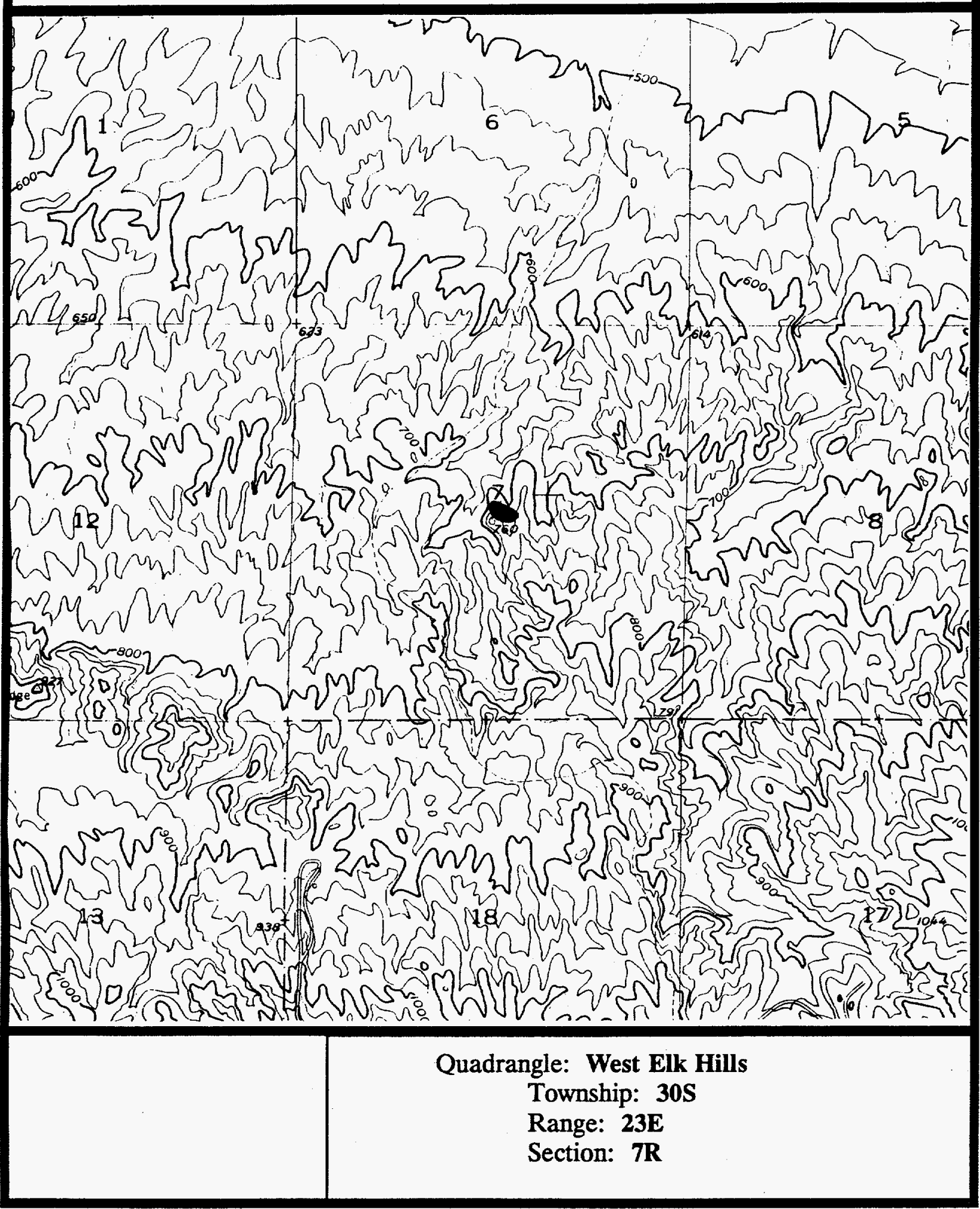




\section{DISTRIBUTION}

DOE/HO

OSTI

(2)

DOE/NV

Technical Information Officer

DOE/NPRC

D. A. Hogan

J. C. Killen

(2)

Chevron U.S.A Production Company

J. M. Brady

D. Vroom

P. Y. O'Brien

Bechtel Petroleum Operation, Inc.

Environmental Services

Department

Enterprise Advisory Services, Inc.

M. Phillips

EG\&G/EM

P.H. Zavattaro

Technical Information Center

EG\&G/EM NV Program

J. Michael

EG\&G/EM ESD

D. C. Anderson

D. A. Craghill

B. L. Cypher

N. Frost

H. J. Hill

T. T. Kato

T. P. O'Farrell

W. K. Ostler
EG8G/EM ESD (continued)

M. R. Otten

L. M. Parks

K. A. Spencer

G. D. Warrick

L. White

BLM

L. Saslaw

S. Carter

R. Lewis

FWS

J. Knight

J. Bartel

P. Cross

J. Brown

CDFG

R. Bitner, NDDB

S. A. Cochran

R. Schlorff

Lake Isabella, California

K. Hammer

Boise, Idaho

G. Holmstead

San Joaquin Endangered Species Recovery Team

D. Williams

E. Cypher 